\title{
Narrow species concepts in the Frullania dilatata-appalachiana- eboracensis complex (Porellales, Jungermanniopsida): evidence from nuclear and chloroplast DNA markers
}

\author{
A. Bombosch • A. Wieneke - A. Busch • \\ R. Jonas $\cdot$ J. Hentschel $\cdot$ H.-P. Kreier $\cdot$ \\ B. Shaw $\cdot$ A. J. Shaw $\cdot$ J. Heinrichs
}

Received: 6 July 2010/ Accepted: 6 September 2010/Published online: 10 October 2010

(C) The Author(s) 2010. This article is published with open access at Springerlink.com

\begin{abstract}
We investigated the phylogeny of a HolarcticAsian group of Frullania species, the Frullania dilatataF. appalachiana-F. eboracensis complex, using multiple accessions of morphologically circumscribed taxa and three molecular markers (nrITS region, cp DNA trnL-F and $a t p \mathrm{~B}-r b c \mathrm{~L}$ regions). Maximum parsimony and likelihood analyses indicated monophyly of morphologically defined taxa. Our phylogenies support a species rather than a subspecies concept within the complex, with four species in North America (F. appalachiana, F. eboracensis, $F$. parvistipula and $F$. virginica), and two species in Europe ( $F$. dilatata and $F$. parvistipula). Accessions of $F$. dilatata from Southeast Europe and Asia are separated from other European accessions, indicating a former disjunct range of the species.
\end{abstract}

Keywords Chloroplast DNA - Distribution range . Frullania $\cdot$ Holarctic $\cdot$ nrITS $\cdot$ Porellales

\footnotetext{
A. Bombosch - A. Wieneke - A. Busch - R. Jonas ·

J. Hentschel · H.-P. Kreier · J. Heinrichs ( $)$

Department of Systematic Botany, Albrecht von Haller Institute of Plant Sciences, Georg August University, Untere Karspüle 2, 37073 Göttingen, Germany

e-mail: jheinri@uni-goettingen.de
}

Present Address:

J. Hentschel

Institute of Systematic Botany with Herbarium Haussknecht and Botanical Garden, Friedrich Schiller University,

Philosophenweg 16, 07743 Jena, Germany

B. Shaw · A. J. Shaw

Department of Biology, Duke University,

Durham, NC 27708, USA

\section{Introduction}

The cosmopolitan liverwort genus Frullania Raddi is easily recognized by its reddish colour and the incubously, narrowly inserted, complicate-bilobed leaves with the lobule often forming a water-sac. Many representatives of this genus form large mats, and are important elements of the cryptogamic flora of tropical forests. Frullania is also common in temperate regions of the world. Due to its commonness and large size, Frullania has attracted many researchers who have set up more than 1,000 binomials that may represent an estimated number of 300-375 valid morphospecies (Schuster 1992; Gradstein et al. 2001).

Only recently has Frullania been studied using DNA sequence evidence (Hentschel et al. 2009; Heinrichs et al. 2010). These studies uncovered unexpected relationships and pointed to the need for a refined subgeneric classification. In this context, it was shown that the common Holarctic-Asian F. tamarisci (L.) Dumort. is a complex of at least eight biological species with rather narrow distribution ranges (Heinrichs et al. 2010).

In the study reported here, we investigated the phylogeny of another common Holarctic-Asian group of Frullania species, the $F$. dilatata (L.) Dumort. $-F$. appalachiana R. M. Schust. $-F$. eboracensis Gottsche complex (Schuster 1992). Representatives of this complex are widely distributed throughout the Holarctic, and show a "mosaic distribution of taxonomic criteria" (Schuster 1992: p. 157). This diffuse distribution of character states has led to different taxonomic hypotheses and conclusions about the relationships among taxa (Hattori 1978; Rüegsegger 1986; Schuster 1992; Grolle and Long 2000). Members of the complex share short, helmet-shaped lobules and rounded lobes lacking ocelli, and they grow closely adnate to their substrate. The species differ in their perianth surface (entire 
to tuberculate), length of perianth beak, frequency and type of vegetative distribution, development of cell wall thickenings, and underleaf shape.

\section{Materials and methods}

Taxon sampling and outgroup selection

The taxa studied are listed in Table 1, including GenBank accession numbers and voucher details. DNA vouchers were revised or identified using the determination keys and descriptions provided by Paton (1999), Rüegsegger (1986), Schuster (1992) and Sim-Sim (1999). All taxa were represented by multiple accessions.

Ingroup taxa represent the $F$. dilatata-appalachianaeboracensis complex and its sister species $F$. azorica SimSim et al., and were selected according to the global Frullania phylogeny of Hentschel et al. (2009) and the treatments of Hattori (1978) and Schuster (1992). Based on these papers, $F$. appalachiana, $F$. dilatata, $F$. eboracensis, $F$. parvistipula Steph. [F. eboracensis subsp. parvistipula (Steph.) R.M.Schust. and F. virginica Gottsche [F. eboracensis subsp. virginica (Gottsche) R.M.Schust.] were regarded as members of the complex. The morphologically similar F. britoniae A. Evans (Schuster 1992) is not closely related to the $F$. dilatata-appalachiana-eboracensis complex (Hentschel et al. 2009) and was therefore not included in this study. F. plana Sull. was designated as outgroup taxon for phylogenetic reconstruction.

\section{DNA extraction, PCR amplification and sequencing}

Plant tissue from the distal portions of a few shoots was isolated from collections housed in the herbaria GOET, JE, SAAR, UBC or UNA. Total genomic DNA was purified using an Invisorb Spin Plant Mini Kit (Invitek, Berlin, Germany) prior to amplification. Protocols for PCR were carried out as described previously: $\operatorname{trn} \mathrm{L}-\mathrm{F}$ region as described by Gradstein et al. (2006), at $\mathrm{B}-r b c \mathrm{~L}$ intergenic spacer as described by Feldberg et al. (2010), and nrITS15.8S-ITS-2 region as described by Hartmann et al. (2006). Bidirectional sequences were generated using a MegaBACE 1000 automated sequencing machine using DYEnamic ET Primer DNA sequencing reagent (Amersham Biosciences, Little Chalfont, UK). Sequencing primers were those used for PCR (104 sequences were newly generated for this study; 14 sequences were downloaded from GenBank).

Phylogenetic analyses

All sequences were aligned manually in Bioedit version 7.0.5.2 (Hall 1999). Ambiguous positions were excluded from the alignment and lacking parts of sequences were coded as missing. Maximum parsimony (MP) and maximum likelihood (ML) analyses were carried out with PAUP* version 4.0b10 (Swofford 2000).

MP heuristic searches were conducted with the following options: heuristic search mode, 100 random-additionsequence replicates, tree bisection-reconnection (TBR) branch swapping, MULTrees option on, and collapse zerolength branches off. All characters were treated as equally weighted and unordered. Nonparametric bootstrapping values (Felsenstein 1985) were generated as heuristic searches with 1,000 replicates, each with ten randomaddition replicates. The number of rearrangements was restricted to ten million per replicate. Bootstrap percentage values (BP) above 70 were regarded as good support (Hillis and Bull 1993). Where more than one most parsimonious tree was found, trees were summarized in a strict consensus tree.

The three genomic regions were first analysed separately to check for incongruence. The strict consensus trees of the nonparametric bootstrap analyses were compared by eye to identify conflicting nodes supported by at least $70 \%$ (Mason-Gamer and Kellog 1996). The trees showed no evidence of incongruence. Hence, the datasets were combined.

Modeltest version 3.7 (Posada and Crandall 1998) in conjunction with PAUP* was used to select a model of evolution for the ML analyses of the combined dataset, performing a hierarchical likelihood ratio test and the Akaike information criterion. For the ML analyses a general time reversible model (Tavaré 1986) was chosen with among-site rate heterogeneity modelled as a discrete gamma distribution with four rate categories, and its estimated parameters $(\Gamma)$ (Goldman 1993). The analysis was performed as a heuristic search using five random-sequence addition replicates, MULTrees option on, collapse zero length branches off, and TBR branch swapping. The confidence of branching was assessed with PAUP* using 200 nonparametric bootstrap resamplings generated as heuristic searches. The number of rearrangements was restricted to 5,000 per replicate.

\section{Results}

Of a total of 2,248 molecular characters, 264 were parsimony informative, 50 autapomorphic, and 1,934 constant (Table 2). The MP analysis resulted in 78 trees of 362 steps with a consistency index of 0.93 and a retention index of 0.98. The strict consensus tree is depicted in Fig. 1. A single most likely tree ( $\ln =-5306.4422$, Fig. 2) was found in the ML analysis. The ML topology largely resembled the MP topology. 
Table 1 Taxa used in the present study, including information about the origin of the studied material, voucher information, and the herbarium where the voucher is deposited, as well as GenBank accession numbers

\begin{tabular}{|c|c|c|c|c|c|}
\hline \multirow[t]{2}{*}{ Taxon } & \multirow[t]{2}{*}{ Origin } & \multirow[t]{2}{*}{ Voucher $\left(\right.$ Herbarium $\left.^{\mathrm{a}}\right)$} & \multicolumn{3}{|c|}{ GenBank Acc. Nos. } \\
\hline & & & nrITS & $\operatorname{trn} \mathrm{L}-\mathrm{F}$ & $a t p \mathrm{~B}-r b c \mathrm{~L}$ \\
\hline $\begin{array}{l}\text { F. appalachiana } \mathrm{R} \text {. } \\
\text { M. Schust. }\end{array}$ & USA., North Carolina (I), Haywood Co., 1,500 m & Davison 7888 (UNA) & HQ330382 & HQ330418 & HQ330449 \\
\hline F. appalachiana & USA., North Carolina (II), Jackson Co., 1,650 m & Davison \& Smith 6389 (UNA) & HQ330383 & HQ330419 & HQ330450 \\
\hline F. appalachiana & USA., North Carolina (III), Jackson Co., 1,600 m & Davison \& Smith 6221 (UNA) & HQ330384 & HQ330420 & HQ330451 \\
\hline $\begin{array}{l}\text { F. azorica Sim-Sim, } \\
\text { Sérgio, Mues \& } \\
\text { Kraut }\end{array}$ & Madeira (I), Seixal, $380 \mathrm{~m}$ & $\begin{array}{l}\text { Schäfer-Verwimp \& Verwimp } 25607 \\
\quad \text { (GOET) }\end{array}$ & HQ330385 & HQ330421 & HQ330452 \\
\hline F. azorica & Madeira (II), Ribeiro do Tristão, 200 m & Eckstein 487 (GOET) & HQ330386 & HQ330422 & HQ330453 \\
\hline F. azorica & Madeira (III) & Mues 3743 (SAAR) & HQ330387 & HQ330423 & HQ330454 \\
\hline F. azorica & Madeira (IV) & Mues 3748 (SAAR) & HQ330388 & HQ330424 & HQ330455 \\
\hline $\begin{array}{l}\text { F. dilatata }(\mathrm{L} .) \\
\text { Dumort. }\end{array}$ & British Isles, Cornwall, Tregony, $80 \mathrm{~m}$ & $\begin{array}{l}\text { Wilson \& Bolton Bryo } 02255 \\
\text { (GOET) }\end{array}$ & HQ330389 & - & HQ330456 \\
\hline F. dilatata & Bulgaria, Rhodope Mts., Bačkovo & Hentschel Bryo 0758 (GOET) & $\begin{array}{r}\text { HQ330375/ } \\
\text { FJ380434 }\end{array}$ & FJ380270 & HQ330457 \\
\hline F. dilatata & Georgia (I), Lesser Caucasus, Bordshomi, 1,300-1,700 m & Zündorf 21940 (JE) & HQ330390 & HQ330425 & HQ330458 \\
\hline F. dilatata & Georgia (II), Greater Caucasus, Shatili, 1,700 m & Zündorf 23914 (JE) & HQ330391 & - & - \\
\hline F. dilatata & Greece, Euböa, Ag. Mammas, 980 m & Bergmeier s.n. (GOET) & HQ330392 & HQ330426 & HQ330459 \\
\hline F. dilatata & Germany (I), Baden-Wurttembergia, Herdwangen-Schönach, $580 \mathrm{~m}$ & $\begin{array}{l}\text { Schäfer-Verwimp \& Verwimp } 28687 \\
\text { (GOET) }\end{array}$ & HQ330393 & HQ330427 & HQ330460 \\
\hline F. dilatata & Germany (II), Baden-Wurttembergia, Öhningen, 595 m & $\begin{array}{l}\text { Schäfer-Verwimp \& Verwimp } 28697 \\
\quad \text { (GOET) }\end{array}$ & HQ330394 & HQ330428 & HQ330461 \\
\hline F. dilatata & Germany (III), Hesse, Bad Sooden-Allendorf, 240 m & $\begin{array}{l}\text { Hentschel \& Heinrichs Bryo } 03137 \\
\quad(\text { GOET) }\end{array}$ & HQ330395 & HQ330429 & HQ330462 \\
\hline F. dilatata & Germany (IV), Saarland, Enzweiler, $330 \mathrm{~m}$ & Sesterhenn 5474 (SAAR) & HQ330396 & HQ330430 & HQ330463 \\
\hline F. dilatata & Germany (V), Rhineland-Palatinate, Alzey-Worms, $140 \mathrm{~m}$ & Oesau DNA3 (GOET) & HQ330397 & HQ330431 & HQ330464 \\
\hline F. dilatata & Germany (VI), Baden-Wurttembergia, Wangen-Allgäu, $580 \mathrm{~m}$ & $\begin{array}{l}\text { Schäfer-Verwimp \& Verwimp } 28826 \\
\text { (GOET) }\end{array}$ & HQ330398 & HQ330432 & HQ330465 \\
\hline F. dilatata & Germany (VII), Baden-Wurttembergia, Zell im Wiesental, 726 m & $\begin{array}{l}\text { Schäfer-Verwimp \& Verwimp } 28670 \\
\text { (GOET) }\end{array}$ & HQ330399 & HQ330433 & HQ330466 \\
\hline F. dilatata & Germany (VIII), Hesse, Wendershausen, $191 \mathrm{~m}$ & Eckstein 6896 (GOET) & HQ330400 & HQ330434 & HQ330467 \\
\hline F. dilatata & Italy (I), Apulia, Pugnochiuso & Sauer 3090 (GOET) & HQ330401 & HQ330435 & HQ330468 \\
\hline F. dilatata & Italy (II), Trentino, Folgarida, 1,280 m & $\begin{array}{l}\text { Schäfer-Verwimp \& Verwimp } 28466 \\
\text { (GOET) }\end{array}$ & HQ330402 & HQ330436 & HQ330469 \\
\hline F. dilatata & Italy (III), Trentino, Folgarida, $950 \mathrm{~m}$ & $\begin{array}{l}\text { Schäfer-Verwimp \& Verwimp } 28452 \\
\text { (GOET) }\end{array}$ & HQ330403 & HQ330437 & HQ330470 \\
\hline F. dilatata & Norway, Aust-Agder, Kristiansand & Hentschel Bryo 03221 (JE) & HQ330404 & - & HQ330471 \\
\hline F. dilatata & Switzerland, Niwalden, Wolfenschiessen, $910 \mathrm{~m}$ & Hentschel \& Busch Bryo 02764 (JE) & HQ330405 & HQ330438 & HQ330472 \\
\hline F. dilatata & Turkey, Antalya, Bey Daglari, $150 \mathrm{~m}$ & $\begin{array}{l}\text { Schäfer-Verwimp \& Verwimp } \\
\text { 20703/T (GOET) }\end{array}$ & HQ330406 & HQ330439 & HQ330473 \\
\hline $\begin{array}{l}\text { F. eboracensis } \\
\text { Gottsche }\end{array}$ & Canada, Nova Scotia (I), Victoria Co., Warren Lake & Schofield et al. 96568 (UBC) & HQ330407 & HQ330440 & - \\
\hline F. eboracensis & Canada, Nova Scotia (II), Queens Co., Jake's Landing area & Schofield \& Belland 96881 (UBC) & HQ330408 & HQ330441 & - \\
\hline F. eboracensis & Canada, Prince Edward Island, Dalvay Woodlands & Belland 16039 (UBC) & HQ330409 & HQ330442 & - \\
\hline F. eboracensis & USA., Alabama, Jackson Co., $500 \mathrm{~m}$ & Davison 6875 (UNA) & HQ330410 & HQ330443 & HQ330474 \\
\hline F. eboracensis & USA., North Carolina (I), Haywood Co., 1,500 m & Davison 7889 (UNA) & HQ330411 & HQ330444 & HQ330475 \\
\hline F. eboracensis & USA., North Carolina (II), Swain Co., 600 m & Davison \& Smith 7424 (GOET) & HQ330412 & HQ330445 & HQ330476 \\
\hline F. eboracensis & USA., North Carolina (III), Swain Co., $600 \mathrm{~m}$ & Davison \& Smith 7390 (UNA) & HQ330413 & - & - \\
\hline F. eboracensis & USA., New York, Albany Co., Clarksville, $180 \mathrm{~m}$ & Smith 50725 (UBC) & HQ330414 & HQ330446 & - \\
\hline F. eboracensis & USA., West Virginia, Pocahontas Co., 600-900 m & Davison 5193 (GOET) & $\begin{array}{r}\text { HQ330376/ } \\
\text { FJ380437 }\end{array}$ & FJ380273 & - \\
\hline F. parvistipula Steph. & Georgia, Lesser Caucasus, Bordshomi, 1,900 m & Zündorf 21852 (JE) & HQ330415 & - & HQ330477 \\
\hline F. parvistipula & Italy, Sicily, SE Trapani, $760 \mathrm{~m}$ & Eckstein 4684 (GOET) & $\begin{array}{r}\text { HQ330377/ } \\
\text { FJ380438 }\end{array}$ & FJ380274 & - \\
\hline F. parvistipula & USA., New Mexico (I) & Worthington 32814 (GOET) & $\begin{array}{r}\mathrm{HQ} 330378 / \\
\text { FJ380433 }\end{array}$ & FJ380269 & - \\
\hline F. parvistipula & USA., New Mexico (II), Otero Co., Sacramento Mts., 2,600 m & Worthington 31081 (GOET) & $\begin{array}{r}\text { HQ330379/ } \\
\text { FJ380435 }\end{array}$ & FJ380271 & - \\
\hline F. plana Sull. & USA., West Virginia, Pocahontas Co., 600-900 m & Davison 5236 (GOET) & $\begin{array}{r}\text { HQ330380/ } \\
\text { FJ380432 }\end{array}$ & FJ380268 & HQ330478 \\
\hline
\end{tabular}


Table 1 continued

\begin{tabular}{|c|c|c|c|c|c|}
\hline \multirow[t]{2}{*}{ Taxon } & \multirow[t]{2}{*}{ Origin } & \multirow[t]{2}{*}{ Voucher (Herbarium ${ }^{\mathrm{a}}$ ) } & \multicolumn{3}{|c|}{ GenBank Acc. Nos. } \\
\hline & & & nrITS & $\operatorname{trn} \mathrm{L}-\mathrm{F}$ & $a t p \mathrm{~B}-r b c \mathrm{~L}$ \\
\hline F. plana & USA., Alabama, Marshall Co., $200 \mathrm{~m}$ & Davison 4325 (GOET) & $\begin{array}{r}\text { HQ330381/ } \\
\text { FJ380431 }\end{array}$ & FJ380267 & HQ330479 \\
\hline F. virginica Gottsche & USA., Louisiana, Rapides Parish & Hyatt s.n. (GOET) & HQ330416 & HQ330447 & HQ330480 \\
\hline F. virginica & USA., Alabama, Winston Co., $180 \mathrm{~m}$ & Davison 3550 (GOET) & HQ330417 & HQ330448 & - \\
\hline
\end{tabular}

Sequences in bold were obtained from GenBank

${ }^{\text {a }}$ Herbarium acronyms follow Holmgren et al. (1990)

Table 2 Distribution of constant and phylogenetically informative sites for aligned positions of the three genomic regions

\begin{tabular}{lrrrr}
\hline & $a t p B-r b c \mathrm{~L}$ & trnL-F & ITS1-5.8S-ITS2 & Total \\
\hline $\begin{array}{l}\text { Number of } \\
\quad \text { sites in matrix }\end{array}$ & 704 & 451 & 1,093 & 2,248 \\
Constant & 663 & 423 & 848 & 1,934 \\
Autapomorphic & 11 & 4 & 35 & 50 \\
Parsimony informative & 30 & 24 & 210 & 264 \\
\hline
\end{tabular}

The robust $F$. azorica clade is placed sister to a wellsupported clade representing the $F$. dilatata-appalachiana-eboracensis complex. This clade is divided into two clades with BP values of $>91$. One clade includes multiple accessions of the Eurasian $F$. dilatata, the other clade well bootstrap supported lineages with multiple accessions of F. parvistipula (Georgia, Italy, North America), F. appalachiana (North America), F. eboracensis (North America) and $F$. virginica Gottsche (North America). $F$. virginica is sister to a clade with $F$. appalachiana and $F$. eboracensis in a well-supported sister relationship. $F$. parvistipula forms the sister to the remainder of the complex.

\section{Discussion}

Species versus subspecies concept

in the $F$. dilatata-appalachiana-eboracensis complex

Species concepts in bryophytes are still largely based on morphology. Taxonomic assessments of morphological character states are often subjective, leading to authordependent taxonomic conclusions and fluctuations in estimates of species numbers (Heinrichs et al. 2003). Several taxa of the $F$. dilatata-appalachiana-eboracensis complex have alternatively been treated as species (Grolle 1970; Hattori 1978; Rüegsegger 1986) or subspecies (Schuster 1992). Schuster's argument for a classification of $F$. virginica and $F$. parvistipula as subspecies of $F$. eboracensis was the "mosaic distribution of taxonomic criteria" rather than a lack of discrete characters that would allow a morphological identification of related accessions. On the other hand, Schuster (1983) established species rank for $F$. appalachiana, another taxon closely related to the above complex. He regarded this taxon as most closely related to F. dilatata (Schuster 1983, 1992).

Molecular data allow an evaluation of morphologybased hypotheses (Heinrichs et al. 2009b; Huttunen and Ignatov 2010). In our study, F. appalachiana is placed sister to $F$. eboracensis s.str. with high bootstrap support, and not closely related to $F$. dilatata. The position of $F$. appalachiana within the $F$. eboracensis $-F$. virginica$F$. parvistipula clade requires species rank for all taxa, or alternatively, the reduction of $F$. appalachiana to a subspecies of $F$. eboracensis. We favour species rank because the taxa occur partially sympatrically and can usually easily be identified using morphological evidence. Species rank is also supported by the molecular trees with high bootstrap percentage values for all investigated taxa (Figs. 1 and 2). According to our study, the complex is represented in North America by four species ( $F$. appalachiana, F. eboracensis, $F$. parvistipula, $F$. virginica), whereas two species occur in Europe $(F$. dilatata, F. parvistipula).

\section{Biogeography}

With the exception of $F$. parvistipula, all ingroup representatives have more or less contiguous ranges (Fig. 1). The rather narrow distributional ranges of most ingroup species resemble the situation in the $F$. tamarisci complex (Heinrichs et al. 2010) with several species endemic to parts of the North American continent. The narrow distributional ranges of $F$. eboracensis, $F$. virginica and $F$. appalachiana are perhaps surprising in light of their high dispersal ability. Schuster (1992) explicitly points out that the Eastern North American F. eboracensis is an aggressive colonizer that copiously produces sporophytes. Despite the frequent presence of sporophytes and vegetative reproductive structures (caducous leaves), this species has not colonized Western North America, or other regions of the world. It remains to be tested if the diaspores of this species have a limited germination capacity after longdistance transportation (Van Zanten and Pócs 1981). 


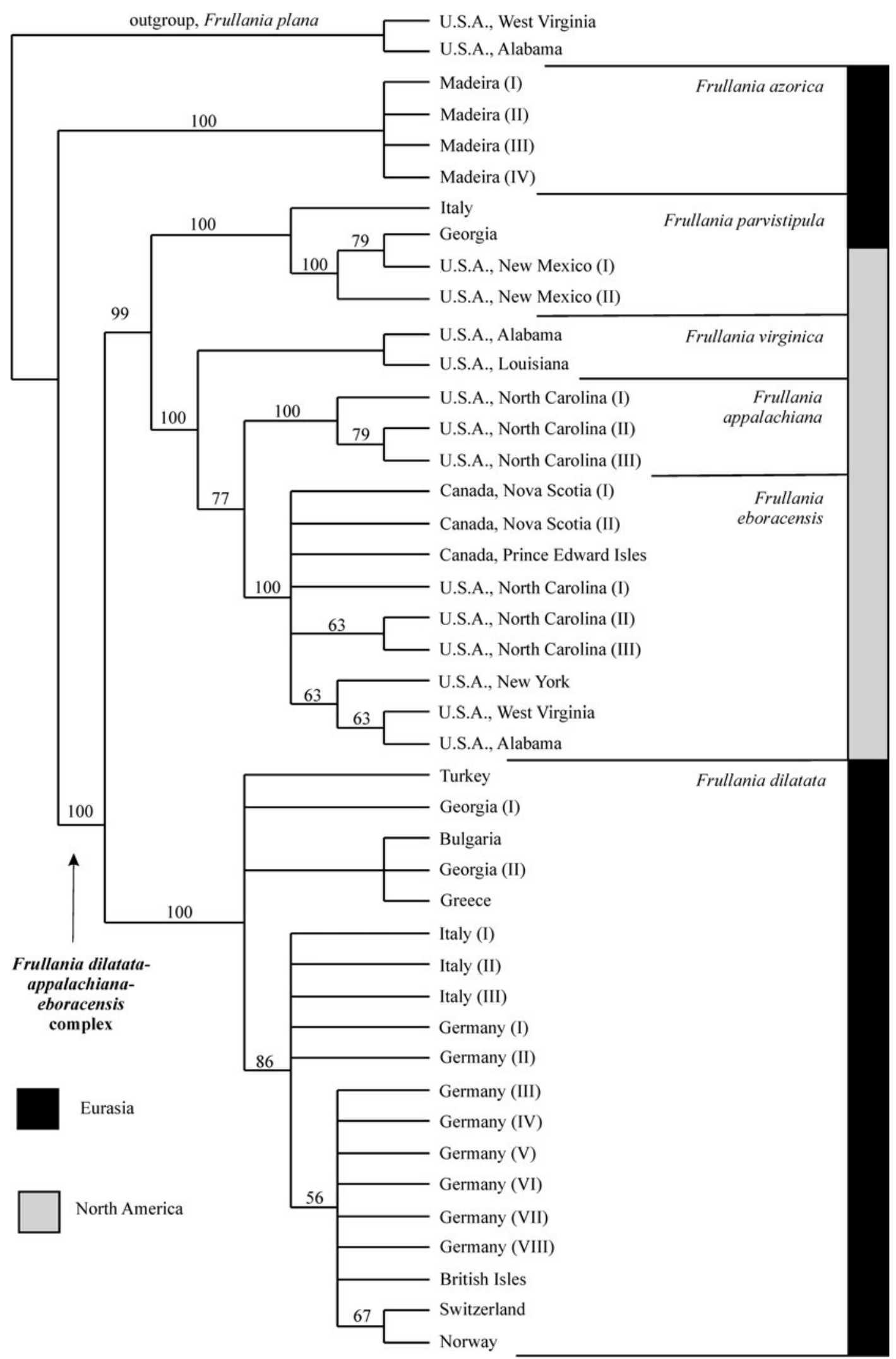

Fig. 1 Strict consensus of 78 equally parsimonious trees with bootstrap percentage values of $>50$ indicated on the branches. Eurasian or North American origin of the accessions is indicated by shaded boxes 


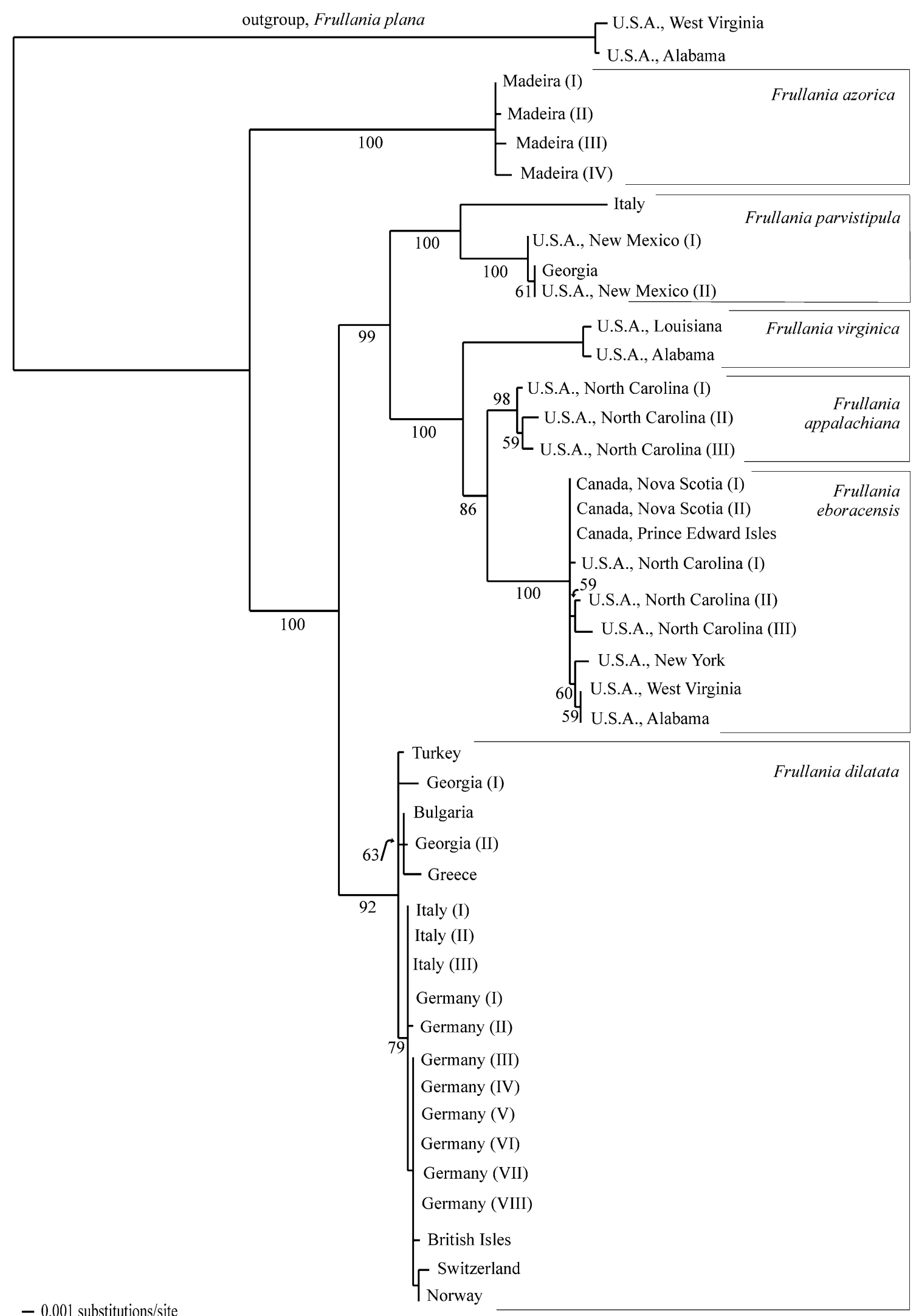

Fig. 2 The single most likely phylogram $(\ln =-5306.4422)$ resulting from the ML analysis of the combined molecular dataset. Bootstrap percentage values of $>50$ are indicated on the branches 
Sequence variation within most ingroup representatives is low, providing some evidence for a relatively recent emergence of these species or extinction and recolonization processes as a consequence of the climate fluctuations of the Pleistocene (Hewitt 2000; Stewart and Lister 2001). Despite the limited sequence variation, there is internal structure within $F$. dilatata that is related to geography. Accessions from Southeast Europe and Asia are separated from other European accessions with good bootstrap support, pointing to a former disjunct range of this species.

Holarctic Frullania species seem to contradict the trend towards a general acceptance of intercontinental ranges of bryophyte species; however, our study confirms the monophyly of the North American-Eurasian range of $F$. parvistipula. Our study corroborates the view that Frullania is a genus that includes both narrow endemics such as $F$. appalachiana and intercontinentally distributed species such as F. ericoides (Nees) Mont. (Hentschel et al. 2009). Intercontinental ranges of bryophytes have been confirmed in several recent molecular studies (Shaw et al. 2003; Davison et al. 2006; Heinrichs et al. 2009b; Yu et al. 2010); however, their frequency seems to vary from genus to genus.

\section{Future prospects}

Molecular data partly confirm previous morphology-based hypotheses; however, there is rapidly growing evidence that morphology alone does not allow an understanding of actual bryophyte diversity (Shaw et al. 2008; Fuselier et al. 2009; Hedenäs 2009). Existing data point to underestimation of the Frullania species diversity by reason of conservative morphology within species complexes (Heinrichs et al. 2010). Hence, appraisals of species numbers and distributional ranges should be based on molecular plus morphological evidence (Heinrichs et al. 2009a). We urgently need more species-level phylogenies with extensive population sampling to approximate the actual diversity of Frullania, and to elucidate speciation processes and distribution range formation.

Acknowledgments We thank Paul G. Davison (Florence), Jan Eckstein (Göttingen), Albert Oesau (Ober-Olm), Támas Pócs (Eger) and Alfons Schäfer-Verwimp (Herdwangen-Schönach) for duplicate material and the directors and curators of the herbaria JE, HIRO, SAAR, UBC and UNAF for the loan of specimens and the permission to extract DNA. Financial support of the German Research Foundation (grant HE 3584/2 to JHEI) and the National Science Foundation (award no. 0531730-003 to A.J.S.) is gratefully acknowledged.

Open Access This article is distributed under the terms of the Creative Commons Attribution Noncommercial License which permits any noncommercial use, distribution, and reproduction in any medium, provided the original author(s) and source are credited.

\section{References}

Davison PG, Smith D, Feldberg K, Lindner M, Heinrichs J (2006) Plagiochila punctata (Jungermanniopsida: Plagiochilaceae) in Tennessee, new to North America. Bryologist 109:242-246

Feldberg K, Váňa J, Long DG, Shaw AJ, Hentschel J, Heinrichs J (2010) A phylogeny of Adelanthaceae (Jungermanniales, Marchantiophyta) based on nuclear and chloroplast DNA markers, with comments on classification, cryptic speciation and biogeography. Mol Phylogenet Evol 55:293-304

Felsenstein J (1985) Confidence limits on phylogenies: an approach using the bootstrap. Evolution 39:783-791

Fuselier L, Davison PG, Clements M, Shaw B, Devos N, Heinrichs J, Hentschel J, Sabovljevic M, Szövenyi P, Schütte S, Hofbauer W, Shaw AJ (2009) Phylogeographic analyses reveal distinct lineages of Metzgeria furcata and $M$. conjugata (Metzgeriaceae) in Europe and North America. Biol J Linn Soc 98:745-756

Goldman N (1993) Statistical tests of models of DNA substitution. J Mol Evol 36:182-198

Gradstein SR, Churchill SP, Salazar-Allen N (2001) Guide to the bryophytes of tropical America. Mem N Y Bot Gard 8686:1-577

Gradstein SR, Wilson R, Ilkiu-Borges AL, Heinrichs J (2006) Phylogenetic relationships and neotenic evolution of Metzgeriopsis (Lejeuneaceae) based on chloroplast DNA sequences and morphology. Bot J Linn Soc 151:293-308

Grolle R (1970) Zur Kenntnis der Frullanien in Europa und Makaronesien. Wiss Z Friedrich-Schiller-Univ Jena Math-Nat Reihe 19:307-319

Grolle R, Long DG (2000) An annotated checklist of the Hepaticae and Anthocerotae of Europe and Macaronesia. J Bryol 22: 103-140

Hall TA (1999) BIOEDIT: a user-friendly biological sequence alignment editor and analysis program for Windows 95/98/NT. Nucleic Acids Symp Ser 41:95-98

Hartmann FA, Wilson R, Gradstein SR, Schneider H, Heinrichs J (2006) Testing hypotheses on species delimitations and disjunctions in the liverwort Bryopteris (Jungermanniopsida: Lejeuneaceae). Int J Plant Sci 167:1205-1214

Hattori S (1978) Notes on the Asiatic species of the genus Frullania. Hepaticae, XI. J Hattori Bot Lab 44:525-554

Hedenäs L (2009) Haplotype variation of relevance to global and European phylogeography in Sarmentypnum exannulatum (Bryophyta: Calliergonaceae). J Bryol 31:145-158

Heinrichs J, Gradstein SR, Groth H, Lindner M (2003) Plagiochila cucullifolia var anomala var. nov. from Ecuador, with notes on discordant molecular and morphological variation in Plagiochila. Plant Syst Evol 242:205-216

Heinrichs J, Hentschel J, Feldberg K, Bombosch A, Schneider H (2009a) Phylogenetic biogeography and taxonomy of disjunctly distributed bryophytes. J Syst Evol 47:497-598

Heinrichs J, Klugmann F, Hentschel J, Schneider H (2009b) DNA taxonomy, cryptic speciation and diversification of the Neotropical-African liverwort, Marchesinia brachiata (Lejeuneaceae, Porellales). Mol Phylogenet Evol 53:113-121

Heinrichs J, Hentschel J, Bombosch A, Fiebig A, Reise J, Edelmann M, Kreier HP, Schäfer-Verwimp A, Caspari S, Schmidt A, Zhu RL, von Konrat M, Shaw B, Shaw AJ (2010) One species or at least eight? Delimitation and distribution of Frullania tamarisci (L.) Dumort. s. 1. (Jungermanniopsida, Porellales) inferred from nuclear and chloroplast DNA markers. Mol Phylogenet Evol 56:1105-1114

Hentschel J, von Konrat MJ, Pócs T, Schäfer-Verwimp A, Shaw AJ (2009) Molecular insights into the phylogeny and subgeneric classification of Frullania Raddi (Frullaniaceae, Porellales). Mol Phylogenet Evol 52:142-156 
Hewitt G (2000) The genetic legacy of the Quaternary ice ages. Nature 405:907-913

Hillis DM, Bull JJ (1993) An empirical test of bootstrapping as a method for assessing the confidence in phylogenetic analysis. Syst Biol 42:182-192

Holmgren PK, Holmgren NH, Barnett LC (1990) Index Herbariorum. Part I: the Herbaria of The World (Regnum Veg. 120), 8th edn. New York Botanical Garden, New York

Huttunen S, Ignatov M (2010) Evolution and taxonomy of aquatic species in the genus Rhynchostegium (Brachytheciaceae, Bryophyta). Taxon 59:791-808

Mason-Gamer RJ, Kellogg EA (1996) Testing for phylogenetic conflict among molecular data sets in the tribe Triticeae (Gramineae). Syst Biol 45:524-545

Paton JA (1999) The liverwort flora of the British Isles. Harley Books, Colchester

Posada D, Crandall KA (1998) Modeltest: testing the model of DNA substitution. Bioinformatics 14:817-818

Rüegsegger F (1986) Frullania parvistipula Steph. (Hepaticae), neu für die Schweiz. Bot Helv 96:61-71

Schuster RM (1983) Notes on Nearctic Hepaticae, XVI. New taxa of Frullania from Eastern North America. Phytologia 53: 364-366
Schuster RM (1992) The Hepaticae and Anthocerotae of North America. East of the hundredth meridian, vol. 5. Field Museum of Natural History, Chicago

Shaw AJ, Werner O, Ros RM (2003) Intercontinental Mediterranean disjunct mosses: morphological and molecular patterns. Am J Bot 90:540-550

Shaw AJ, Boles S, Shaw B (2008) A phylogenetic delimitation of the "Sphagnum subsecundum complex" (Sphagnaceae, Bryophyta). Am J Bot 95:731-744

Sim-Sim M (1999) The genus Frullania Raddi in Portugal and Madeira. Cryptog Bryol 20:83-144

Stewart JR, Lister AM (2001) Cryptic northern refugia and the origins of the modern biota. Trends Ecol Evol 16:608-613

Swofford DL (2000) PAUP*, phylogenetic analyses using parsimony (* and other methods), version 4.01b10. Sinauer Associates, Sunderland

Tavare S (1986) Some probabilistic and statistical problems in the analysis of DNA sequences. Lect Math Life Sci 17:57-86

Van Zanten BO, Pócs T (1981) Distribution and dispersal of bryophytes. Adv Bryol 1:479-558

Yu J, Devos N, Majestyk P, Shaw AJ (2010) Intercontinentally disjunct species are derived rather than relictual in the moss genus Daltonia (Bryophyta). Taxon 59:459-465 